\title{
A knowledge-driven Multi-Criteria Decision Making- Analytical Hierarchy Process based Geospatial Modeling for the Delineation of Fluoride Contamination Zones in Groundwater, Jamui District, Indo-Gangetic Alluvial Plains, India
}

\section{Suresh Kumar}

Central Ground Water Board

\section{Sudhakar Singha}

IIT (ISM): Indian Institute of Technology

\section{Rambabu Singh}

CMPDIL,Bilaspur

Venkatesh Satya Akella ( $\nabla$ akellasatyavenkatesh@gmail.com )

Indian School of Mines: Indian Institute of Technology https://orcid.org/0000-0002-3342-4374

Utpal Gogoi

Central Ground Water Board,Faridabad

\section{Research Article}

Keywords: Fluoride contamination, MCDM-AHP, Geospatial technology, Jamui, Indo-Gangetic Alluvial Plains

Posted Date: February 22nd, 2021

DOl: https://doi.org/10.21203/rs.3.rs-175060/v1

License: (c) (i) This work is licensed under a Creative Commons Attribution 4.0 International License. Read Full License 
A knowledge-driven Multi-Criteria Decision Making- Analytical Hierarchy Process based geospatial modeling for the delineation of fluoride contamination zones in groundwater, Jamui district, Indo-Gangetic alluvial plains, India

$$
\begin{gathered}
\text { Suresh Kumar }{ }^{1 \& 4} \text {, Sudhakar Singha }{ }^{2} \text {, Rambabu Singh }{ }^{3}, \text { A. S. Venkatesh }{ }^{4 *} \\
{ }^{1} \text { Central Ground Water Board, Patna-800001, India. } \\
{ }^{2} \text { Department of Civil Engineering, Indian Institute of Technology (Indian School of Mines), } \\
\text { Dhanbad-826004, Jharkhand, India. } \\
{ }^{3} \text { Central Mine Planning and Design Institute Limited, Bilaspur-495006, India } \\
{ }^{4} \text { Department of Applied Geology, Indian Institute of Technology } \\
\text { (Indian School of Mines), Dhanbad-826004, India. } \\
\left({ }^{*}\right. \text { Corresponding author:asvenkatesh@itism.ac.in) }
\end{gathered}
$$

\section{Abstract}

This study presents a framework to delineate the potential fluoride contamination zones within the groundwater of the study area by employing GIS coupled with Multi-Criteria Decision Making-Analytical Hierarchy Process approach (MCDM-AHP). In this context, various groundwater contamination controlling hydrogeo-meteorological factors thematic layers were prepared in the GIS environment and assigned with an appropriate rating and weights. All the selected influencing factors were overlaid using a weighted overlaid index approach after normalizing the weights and ratings of the respective layers using the AHP technique and then computed the fluoride contamination zones (FCZs). The obtained results indicate that $61.50 \%$ $\left(1101.82 \mathrm{~km}^{2}\right)$ of the total study area was delineated as a relatively safe zone $(\mathrm{F}<1.5 \mathrm{mg} / \mathrm{L})$ and the remaining $38.50 \%\left(689.18 \mathrm{~km}^{2}\right)$ was demarcated under the unsafe zone $(\mathrm{F}>1.5 \mathrm{mg} / \mathrm{L})$. The proposed FCZs model corroborates a significant agreement of $85 \%$ with the 61 observed locations and thus testify to the model reliability.

Keywords: Fluoride contamination, MCDM-AHP, Geospatial technology, Jamui, Indo-Gangetic Alluvial Plains. 


\subsection{Introduction}

30 Fluoride is one of the essential and helpful elements for human health as it is associated with

31 bone mineralization and dental enamel formation (Rahman et al., 2020; Gonçalveset al., 2020;

32 Mondal et al., 2009). Moreover, some health issues are common, especially in children, such as

33 deficiency in bone mineralization, dental enamel formation, dental caries, when the amount of

34 fluoride consumed daily is less than $0.5 \mathrm{mg} / \mathrm{L}$ (Kumar et al., 2019). At the same time, the consumption of drinking water with a fluoride concentration of more than $1.5 \mathrm{mg} / \mathrm{L}$ leads to fluorosis, which is common in both adults and children (Kumar et al., 2019). Children and the

37 younger populations in the fluoride endemic areas are highly affected by mottled enamel (Yuan et al., 2017). Consumption of fluoride enriched groundwater develops symptoms of skeletal

39 fluorosis such as pain related to bones and joints in elderly people (Sawangjang et al., 2019). It has been observed that these symptoms in a long run turn into permanent disability (Liu et al., $412015)$.

42 The incidence of fluorosis and its severity is due to the presence of fluoride content in water and 43 soil. Prolonged consumption of fluoride enriched groundwater is a crucial contributor 44 responsible for the waterborne fluorosis in human beings (Singh et al., 2017a and b, Su et al., 45 2019). The chemical composition of hinterland geology or lithological unit is closely related to 46 the higher groundwater fluoride concentration (Singha et al., 2019a; Singh et al., 2018). Many

47 scholars in their studies have highlighted that higher fluoride levels in the groundwater of 48 granitic and metamorphic rock terrains were ascribed to the release of fluoride ion from the host 49 rocks (Shanker et al., 2003; Thapa et al., 2017; Su et al., 2019; Narsimha et al., 2019).

50 Geological materials consisting of fluoride-rich minerals such as fluorite, apatite, wohlerite, 51 tourmaline, herderite, sphene, hornblende series minerals, muscovite, actinolite and fluor-apatite 
52 can trigger fluoride enrichment in aquifer solution through prolonged rock-water interaction

53 (Todd and Mays, 2005; Rao., 2009, Adimalla and Venkatayogi, 2017). Several clay minerals,

54 namely smectite, illite and chlorite also contribute significantly to fluoride concentration in

55 solution (Tossou et al., 2017). In recent times, several researchers have opinioned that climate,

56 evaporation, adsorption-desorption, ion exchange, ion competition, alkaline environmental

57 conditions, lithology, and geomorphology of the area are the significant factors that can produce

58 fluoride enriched groundwater (Mondal et al., 2009; Luo et al., 2018; Vithanage et al., 2014).

59 The higher the surface drainage density more is the surface runoff of rainfall and scanty is the

60 infiltration to groundwater storage.

61 Fluoride contamination commonly increases when lesser infiltration of rainwater occurs (Thapa

62 et al., 2017). A flat ground surface leads to higher infiltration due to its less drainage density,

63 which may result in higher leaching of fluoride in the aquifer. Besides this, the existence of

64 fracture density in rocks is predominantly responsible for the higher propagation of fluoride

65 values in groundwater (Kim and Jeong, 2005). Moreover, certain anthropogenic activities viz.,

66 domestic sewage, excessive utilization of phosphate fertilizers and pesticides in the crop fields

67 and long-time irrigation practices are also accountable for higher fluoride levels in groundwater

68 storage through leaching (Dartan et al., 2017; Srivastava and Ramanathan, 2018). The presence

69 of excess fluoride content in the subsurface water resources has now drawn global attention as

70 one of the most detrimental menaces to human health and geo-environmental problems in India

71 and other parts of the world (Ando et al., 2001; Pillai and Stanley., 2002; Madhnure et al., 2007).

72 The present study area comprises thick granitic litho-units and initially, the elevated fluoride

73 levels in groundwater were reported in some locations of the study area by the Central Ground

74 Water Board (CGWB, 2013) in which granitic activity is prevalent. Later on, Kumar et al., (2017 
75 and 2019) studied contamination of groundwater with respect to fluoride and its dynamic effects

76 were assessed with the aid of hydro-geochemical signatures, chemometric methods and medical

77 geological aspects. Notwithstanding, to the best of the knowledge of the authors, none of the

78 studies have been reported on exploring and verifying the geospatial modeling for identification

79 of fluoride contamination zones in the research area, where the study area is particularly

80 important as it is characterized by both crystalline and alluvial aquifer units. Hence, in the

81 current investigation, a knowledge driven Multi-Criteria Decision Making- Analytical Hierarchy

82 Process (MCDM - AHP) approach coupled with the GIS environment has been exercised for

83 delineating the spatial distribution of groundwater fluoride contamination regions in parts of

84 Jamui district, Bihar, India. The main objectives of the study comprise of mapping fluoride

85 affected hazardous zones by considering various geological features and assigning their

86 optimized MCDM - AHP based weight/ratings for the computation of FCZ indices. Finally, the

87 verification of the FCZ map was carried out with measured fluoride concentrations to evaluate

88 the proposed model performance through which the prognostication of fluoride contamination

89 zones can be planned.

$90 \quad 2.0$ Study area

91 The proposed study area is a part of Jamui district in the state of Bihar, India and lies between

92 North latitude $24^{0} 40^{\prime}$ to $25^{0} 10^{\prime}$ and East longitude $85^{\circ} 50^{\prime}$ to $86^{0} 35^{\prime}$ with a total extent of 1791

$93 \mathrm{~km}^{2}$. The geology of the study area is composed of rocky upland, pediplain and alluvial plains.

94 Alluvial plains in the study area were formed by continental Quaternary deposits and is a part of

95 the Jamui Formation and is generally termed as "older alluvium" in Indian geology. The major

96 rock types which cover the region are quartzite, quartz-mica schist, biotite-muscovite schist,

97 granites, composite gneisses, pegmatite, amphibolite and quartz veins. The most potential 
aquifers are common in the alluvial formation. The thickness of the alluvium gradually increases towards the north and finally merges with the Gangetic alluvium, south of the River Ganga. The total thickness of the alluvium ranges from $90 \mathrm{~m}$ in the northern part and is finally reduces to less than $12 \mathrm{~m}$ in the southern part. Some other landforms like, escarpment, inselbergs and valley fills are also present in the area. Humid climate dominates the area and is the driving factor responsible for the weathering of the overlying mantle. Elevated fluoride concentration in the groundwater of the study area might have been generated due to weathering of this fluoride bearing material from granite, granite-gneiss, amphibolites and mica-schists and deposition of same over the parent rock as a weathered mantle. A tropical southwestern monsoon climate governs the area with an average annual precipitation of $1042 \mathrm{~mm}$. Infiltration from monsoon rainfall contributes to the major part of the recharge of aquifers.

\subsection{Materials and methods}

High density polyethylene bottles (HDPE) were used for the collection of water samples for fluoride analysis. Sample bottles were cleaned several times using distilled water prior to sampling. A total of 61 groundwater samples were collected in the month of May 2014 for the estimation of fluoride. The samples were analyzed for fluoride concentration using Systronic make UV-VIS spectrophotometer (2202) within two weeks after the collection of samples. The standard procedure provided by the American Public Health Association (APHA 2012) was strictly adhered during analysis.

\subsection{Development of thematic layers}

In order to delineate fluoride contaminated zones, a total of 10 separate thematic layers were prepared for the investigation using conventional chemical data, remote sensing (RS) and Arc 
121 GIS 10.3. The thematic layers include aquifer (A), geomorphology (G), soil texture (S), 122 slope/topography (T), elevation (E), drainage density (D) and distribution of rainfall (R), depth to 123 water table (D), land use land cover (LULC) and lineament density (L). Details of the thematic 124 layers are given in Table 1. The methodology followed is shown in Fig. 1. Geomorphological 125 details of the region were prepared with the help of the groundwater information booklet Jamui 126 district, Bihar, India (CGWB, 2007). Digital elevation model (SRTM, USGS) of 30 m resolution 127 was applied to prepare the slope and elevation map of the study region. Pre-monsoon water table 128 depth for 31 locations was measured for the entire study area in the year 2014. The lineament 129 and land use pattern data were collected form the National Remote Sensing Centre (NRSC), Hyderabad. The study area soil map was prepared from data obtained from the National Bureau 131 of Soil Survey and Land Use Planning (NBSSLUP). Rainfall data for 2013 to 2017 was compiled from Indian Meteorological Department (IMD) and the geological map used to be after 133 the Geological Survey of India (1987).

"Figure 1 is about here"

3.2 Weight assignment and weight normalization factors using AHP

The Analytical Hierarchical Process (AHP), is a very effective approach for handling the 137 complexity of real world decision-making problems, developed by Saaty (1980). A knowledge driven AHP-based multi-criteria decision analysis (MCDM) is a very much popular parameter 139 weight prioritization approach in the prognostication of contaminants. AHP is an effective tool, 140 which reduces the complexity associated with decision making problems into a series of pair141 wise comparisons and then synthesizes the outcome of the final results (Arulbalaji et al., 2019). 142 In addition, the AHP-based MCDM approach is also a suitable evaluation technique to evaluate 143 the consistency of final output; accordingly, it reduces the conflict involved in the decision- 
144 making process. Based on the above facts, in the current research work, a combined approach of 145 AHP and GIS technique is used to delineate the fluoride contaminated zones of the area under 146 study. The chosen ten thematic layers were supposed to be accountable for enhanced fluoride 147 concentration in the study region. Hence, the influencing factors were weighted according to 148 their contribution to groundwater contamination, especially with respect to fluoride, field study 149 and keeping in mind review of past studies. A layer with a higher weight illustrates a parameter 150 with a higher contribution towards groundwater contamination and vice versa. According to 151 Saaty's scales (1980) of relative importance value, assigned weights for selected factors are as 152 follows: similar importance (scale-1), moderate importance of one over another (scale-3), strong 153 importance (scale-5), very strong importance (scale-7), extreme importance (scale-9), 154 intermediate values between the two adjacent judgments (scale-2, 4, 6, 8), reciprocal for inverse 155 comparison (scale-reciprocals of the above nonzero numbers). After the weight assigned to the 156 respective factors, the relative comparison of all the factors with each other was structured to 157 form a pair-wise comparison matrix (Table 2).

159 Pair-wise comparison matrix (Table 2) constructed for the thematic layers is in following 160 accordance:

$$
M=\left[\begin{array}{ccc}
A_{11} & A_{12} . & A_{1 n} \\
A_{21} & A_{22} . & A_{2 n} \\
: & : & : \\
A_{f 1} & A_{f 2} . & A_{f n}
\end{array}\right]
$$

163 Computed pair wise comparison matrix $\left(\mathrm{M}=\left[A_{f n}\right]\right)$ is demonstrated in Table 2 and has been 164 exhibited by applying equation: 


$$
A_{f n}{ }^{\prime \prime}=\frac{A_{f n}}{\sum_{f=1}^{x} A_{f n}}
$$

166 Where, $n=1,2,3,4,5, \ldots \ldots x, A_{f n}$ represents the element of $f$ row besides $n$ column of matrix.

The normalized weight $\left(w_{x}\right)$ was calculated utilizing Eq. 3.

$$
w_{x}=\frac{\sum_{n=1}^{x} A_{f n}{ }^{\prime}}{x}
$$

170 Where, $f=1,2,3,4,5, \ldots \ldots . . x$

171 (c) Examination of uncertainty in judgment

172 Then to examine the uncertainty, Satty (2004) proposed the principal eigenvalue and consistency 173 index and to examine the uniformity of judgment matrix, the consistency ratio.

174 Hence, for computing the consistency ratio (CR), the procedure adopted is as follows: (1) first of 175 all, Principal Eigenvalue ( $\lambda$ ) was figured out by Eigenvector technique and (2) secondly, 176 Consistency Index (CI) was computed using the Eq. 4

$$
C I=\frac{\lambda_{\max }-n}{n-1}
$$

178 In the above mentioned equation, $n$ represents no. of thematic layers $(n=10$ in this case) 179 whereas $\lambda_{\max }$ represents the maximum eigenvalue of the pair-wise comparison matrix.

180 Ultimately, Consistency ratio (CR) was derived by using Eq. 5.

$$
C R=\frac{C I}{R C I}
$$

182 Where $C I$ represents the consistency index and $R C I$ denotes the random consistency index, 183 respectively. $R C I$ values are considered from Saaty's (1980), 1-9 point scale for the selected 
184 number of parameters. Saaty's ratio index (RCI) for corresponding numbers of parameters (n) is 185 as follows: n-1 (RCI-0), n-2 (RCI-0), n-3 (RCI-0.52), n-4 (RCI-0.89), n-5 (RCI-1.11), n-6 (RCI186 1.25), n-7 (RCI-1.35), n-8 (RCI-1.10), n-9 (RCI-1.45) and n-1 (RCI-1.49). Satty (1980) 187 advocated that CR value less than $10 \%$, defends the consistency in the pair-wise comparison. In 188 this study, the CR value is $5.5 \%$ and thus withstands the consistency.

189 The normalized computed weights for all the thematic layers were finalized for further analysis. 190 Thereafter, the subclasses of thematic layers were re-classified in the GIS platform. The ratings 191 of subclasses of each thematic layer were allocated on a gradation of 1 to 9 , according to their 192 relative significance with respect to the contribution to the groundwater fluoride contamination.

\section{$193 \quad 3.3$ Weighted overlay index-based approach (WOIA)}

194 The WOIA method is utilized by a good number of researchers globally in different regions in 195 varying hydro-geologic settings (Elewa and Qaddah., 2011; Ghazavi and Ebrahimi., 2015; Al196 Abadi et al., 2017; Singha et al., 2017; Thapa et al., 2018). The ratings and weights of all the ten 197 layers were multiplied and summed up together to demarcate fluoride contaminated zones 198 (FCZ). FCZ for the study area has been computed by using the following equation:

$$
F C Z=\sum_{1}^{n}\left(P_{r} Q_{w}\right)
$$

200 Where $P$ and $Q$ denote the parameters and subscript $r$ and $w$ are the respective ratings designated 201 to parameter subclasses and weights to each parameter class. Hence, this is the most well-known, 202 simple and flexible method for integrating all the thematic layers in the GIS environment. 203 Accordingly, the final fluoride contamination zone map was classified into two categories, 204 namely, safe and unsafe zone. 


\section{$206 \quad 4.0$ Results and discussion}

\section{4.1 Role of Hydrogeo-meteorological factors and groundwater quality}

208 Dynamic groundwater resource of the phreatic aquifer in the study area gets replenished each

209 year, mainly by diffuse rain fed recharge apart from that managed recharge consisting of planned

210 and unplanned recharge through various artificial recharge structures and seepage from water

211 bodies and irrigation fields. Water that recharges the groundwater, gets altered during its course

212 of infiltration and precipitation thereby acquire mixed quality depending on the source and

213 passing media (i.e. Hydrogeo-meteorological parameters). Therefore, groundwater quality and its

214 occurrence is dependent upon various hydrogeo-meteorological factors viz., aquifer media, 215 geomorphology, soil texture, slope, elevation, drainage density, rainfall distribution, depth to the

216 water table, land use land cover and lineament density. On the basis of each parameter

217 characteristics and significance in terms of potential groundwater contamination with respect to

218 fluoride, relative rating and weights have been assigned and fluoride contaminated zones (FCZ)

219 were demarcated after building of each thematic layer as mentioned in the following section.

220 Aquifer media imparts a vital role in absorption, storage, the transmission of water and the

221 residence time of groundwater. The coarser the aquifer material, the lesser is the residence time

222 and lesser the chances of groundwater contamination and vice versa. Based on the aquifer

223 characteristics (media), the study area was categorized into four classes, viz., alluvial, biotite-

224 muscovite-chloride schist, granite gneiss, quartzite, quartz schist and phyllite extending over an 225 area of around $113 \mathrm{~km}^{2}, 818 \mathrm{~km}^{2}, 506 \mathrm{~km}^{2}$ and $353 \mathrm{~km}^{2}$ respectively. The aquifer map of the 226 study region is shown in Fig. 2a.

227 Geomorphologic patterns are generally known as the surface indicators revealing the conditions 228 for groundwater occurrence of a region (Preeza et al., 2011). Moreover, it also reflects the 
underlying geological formation that is responsible for groundwater occurrence, storage, transmission and its residence time. Hence, the geomorphology of the study area plays an important role in groundwater studies (Machiwal et al., 2011; Singha et al., 2019b). In the study area, Quaternary alluvial plains occupy an area of about $463 \mathrm{~km}^{2}$, denudational hills and piedmont covers an area of about $730 \mathrm{~km}^{2}$ and pediplain covers an area of about $598 \mathrm{~km}^{2}$ respectively. The geomorphological pattern of the study area is shown in Fig. 2 b.

Soil texture is one of the influencing factors considered for any groundwater-related studies as it exhibits the infiltration rate of the soil media through which water flows and reaches the aquifer. The coarser the soil media, the lesser will be the holding capacity and more will be the chances of contaminants to reach the aquifer and vice versa. In the study area, coarse loamy soil extends over an area of about $458 \mathrm{~km}^{2}$ approximately, whereas fine loamy soil extends over an area of about $1333 \mathrm{~km}^{2}$. Coarse loamy soil has been assigned higher weightage due to its high infiltration rate. The soil texture map of the study area is shown in Fig. 2c.

The slope is another important factor in groundwater studies, that greatly influences the recharge of groundwater, i.e., gentle to flat slopes will contribute to less runoff, thereby increases the infiltration rate and groundwater contamination. On the contrary, segments of the study area, with higher slope (steep slope) results in a higher runoff, lower infiltration rate and consequently reduces the chances of groundwater contamination. According to the slope, the study area was categorized into five classes such as $0-3 \%, 3-6 \%, 6-9 \%, 9-12 \%$ and more than $12 \%$ encompassing over an area of approximately, $654 \mathrm{~km}^{2}, 626 \mathrm{~km}^{2}, 210 \mathrm{~km}^{2}, 65 \mathrm{~km}^{2}$ and 236.99 $\mathrm{km}^{2}$ respectively. The slope map of the study area is shown in Fig. $2 \mathrm{~d}$.

\section{"Figure 2 is about here"}

Elevation and slope of a region signify the storage of groundwater, i.e., a lower slope tends to higher groundwater storage in comparison to the areas with steeper slope (Thapa et al., 2017). In 
253 the study area, around $1415 \mathrm{~km}^{2}$ area falls in an elevation varying from $42-167 \mathrm{~m}, 297 \mathrm{~km}^{2}$ falls 254 in between $167-292 \mathrm{~m}, 70 \mathrm{~km}^{2}$ falls within 292 to $417 \mathrm{~m}$ and $9 \mathrm{~km}^{2}$ area falls in between $417-542$

255 m respectively. The elevation map of the study area is shown in Fig. 2e.

256 Drainage density is known as the proximity of the spacing of the flow channels. The drainage 257 density is inversely correlated to the permeability factor. Drainage density is inversely related to 258 the permeability of aquifers (Arulbalaji et al., 2019). The higher drainage density of an area 259 indicates the presence of a less permeable lithological unit resulting in more runoff within the 260 region (Rashid et al., 2012). Hence, higher drainage density indicates low recharge and lower 261 chances of subsurface water contamination and vice versa (Bagyaraj et al., 2013). In the study 262 area, drainage density was classified into five categories such as $0-3 \mathrm{~km} / \mathrm{km}^{2}$ encompassing over 263 an area of around $1264 \mathrm{~km}^{2}, 3-6 \mathrm{~km} / \mathrm{km}^{2}$ extending over an area of about $369 \mathrm{~km}{ }^{2}, 6-9 \mathrm{~km} / \mathrm{km}^{2}$ 264 with $104 \mathrm{~km}^{2}, 9-12 \mathrm{~km} / \mathrm{km}^{2}$ with $45 \mathrm{~km}^{2}$ and more than $12 \mathrm{~km} / \mathrm{km}^{2}$ accounts for $9 \mathrm{~km}^{2}$ 265 approximately in the study area respectively. The drainage density map of the study region in the 266 Jamui district is shown in Fig. $2 \mathrm{f}$.

267 Intensity, duration, and distribution of rainfall in a region also impart a vital role in respect to 268 infiltration and contamination rate. Higher intensity and shorter duration infer the higher rate of 269 runoff and lower infiltration, hence lower chances of groundwater contamination and conversely 270 (Ibrahim-Bathis and Ahmed, 2016). The study area experiences an annual rainfall varying from $271718 \mathrm{~mm} /$ year to $1071 \mathrm{~mm} /$ year and was classified accordingly into three subclasses such as 718$272835 \mathrm{~mm}$ (around $117 \mathrm{~km}^{2}$ of total area), 835-952 mm (1225 $\left.\mathrm{km}^{2}\right)$ and more than $952 \mathrm{~mm}(449$ $273 \mathrm{~km}^{2}$ ) respectively. The rainfall distribution map of the study area is shown in Fig. $2 \mathrm{~g}$.

274 Depth to the water table is one of the most significant parameters amongst other selected 275 parameters as it depicts the thickness (band) of material through which contaminant travels from 
276 the surface to the groundwater table before reaching an aquifer. The deeper the water table depth,

277 the lesser the possibilities of contaminants to reach within subsurface water (Senthilkumar et al., 278 2014). Pre-monsoon water table depth has been considered for the study and was classified into 279 four categories, i.e., 0-3 m, 3-6 m, 6-9 m, more than $9 \mathrm{~m}$ which encompasses over an area of 280 around $5 \mathrm{~km}^{2}, 1138 \mathrm{~km}^{2}, 634 \mathrm{~km}^{2}$, and $15 \mathrm{~km}^{2}$ respectively. The range of depth to water table 281 varies in the study area from $1.93 \mathrm{~m}$ to $12.06 \mathrm{~m}$. The depth to water table map is shown in Fig. $2822 \mathrm{~h}$.

283 Land Use Land Cover (LULC) is considered as one of the important parameters as it is 284 intimately associated with the groundwater quality of an area and also refers to all the activities 285 that occur on the land surface (Wu et al., 2016). In the present study, LULC was classified into 286 six categories, namely, barren rocky land with occasional scrubs, cropland, fallow land, forest 287 and plantation, rural and urban settlements and water bodies, which covers an area of about 287 $288 \mathrm{~km}^{2}, 611 \mathrm{~km}^{2}, 359 \mathrm{~km}^{2}, 407 \mathrm{~km}^{2}, 66 \mathrm{~km}^{2}$, and $61 \mathrm{~km}^{2}$ respectively. The LULC map is shown in 289 Fig. 2i.

290 The lineaments in the geological units are mainly the linear fractures detected on satellite images 291 and aerial photographs. Several researchers have advocated the positive relationship between 292 groundwater flow and yield with respect to the lineament density. Thus, detailed information on 293 the presence of lineaments in sub-surface lithological units are very important for groundwater 294 development and management studies (Al-Rawabdeh et al., 2015). The possibility of 295 groundwater pollution is increased due to the availability of higher lineament density that 296 promotes the infiltration of contaminants into groundwater. In the present study, lineament 297 density was classified into six subclasses i.e., $0-0.5 \mathrm{~km} / \mathrm{km}^{2}$, which encompasses over an area of 298 about $1391 \mathrm{~km}^{2}, 0.5-1 \mathrm{~km} / \mathrm{km}^{2}, 1-1.5 \mathrm{~km} / \mathrm{km}^{2}, 1.5-2.0 \mathrm{~km} / \mathrm{km}^{2}, 2-2.5 \mathrm{~km} / \mathrm{km}^{2}$ and more than 2.5 
$299 \mathrm{~km} / \mathrm{km}^{2}$ extends over an area around $157 \mathrm{~km}^{2}, 61 \mathrm{~km}^{2}, 51 \mathrm{~km}^{2}, 33 \mathrm{~km}^{2}$ and $91 \mathrm{~km}^{2}$ respectively.

300 The prepared lineament density map is shown as Fig. 2 j.

301

302

303

304

305

306

307

308

309

310

311

312

313

314

315

316

317

318

319

320

321

\section{2 Delineation of potential fluoride contaminated zones (FCZ)}

As discussed earlier in section 3.2, factors weight and rating were assigned based on a knowledge based AHP-based multi-criteria decision analysis (MCDM) and then potential fluoride contaminated zones (FCZ) map was obtained by overlaying all the ten thematic layers in Arc GIS 10.3 software. Figure 3(a) illustrates the distribution of potential fluoride contaminated zones in the study area that implied the maximum and minimum indices values of the final output within a range of 4.05 to 8.29 . Thereafter, by using the "jenks natural breaks", the FCZ map was classified into two categories namely, safe and unsafe zones with respect to fluoride contamination. The safe zone means an area having fluoride concentration less than $1.5 \mathrm{mg} / \mathrm{L}$, whereas, the unsafe zone indicates the area with fluoride concentration higher than the permissible limit, i.e., above $1.5 \mathrm{mg} / \mathrm{L}$ (BIS, 2012).

Based on the FCZ map (Fig. 3a), some parts of the study region belong to the safe category covering an area of $1101.82 \mathrm{~km}^{2}(61.52 \%$ of the total area). Groundwater from these zones is suitable for drinking and other uses whereas, mostly the southeastern, southwestern parts and a few stretches in the upper central northern portions were reflected as higher fluoride contamination zones/ unsafe zones, covering an area of about $689.18 \mathrm{Km}^{2}(38.48 \%$ of the total area) was unsuitable for drinking. Afterward, the reported unsafe zones were compared with the geology of the area which indicates that these regions were underlain by granite-gneiss/granites with intensely fractured basement rocks. The relatively higher ratings assigned to the existing litho-units and structural features, including faults during the model computation process and are forming the basis for assigning these areas as responsible as unsafe zones. 
322 Furthermore, the results of the present study are in concurrence with the earlier studies

323 conducted by Kumar et al., (2017 and 2019) with the aid of hydro-geochemical signatures that

324 the elevated fluoride values are reported in the study area were of the geogenic source (granite

325 gneiss). Additionally, barren rocky land with occasional scrubs and the existence of cropland

326 may also contribute to elevated fluoride in groundwater being one of the prime anthropogenic

327 sources in a few places albeit to the lower extent. Similarly, the presence of pediplains and 328 relatively high rainfall distribution were also one of the leading factors responsible for the 329 contribution of high fluoride concentration which in turn results in an unsafe zone.

"Figure 3 is about here"

\section{4. 3 Validation of the proposed fluoride contamination zone (FCZ) map}

332 In general, the AHP-based MCDM approach works with certain assumptions while assigning 333 ratings and weights purely based on the inputs provided by the modeler. Any error or imprecise 334 invoking of input parameters into the model may lead to erroneous results and thereby by the 335 failure of the approach. Therefore, it is imperative to validate the results obtained through the 336 knowledge based AHP-based MCDM approach model with the real ground conditions, in order 337 to avoid the uncertainties, if any. This will also ensure the accuracy and precision of the model. 338 For this sake, sixty-one groundwater samples covering the entire study area were collected 339 during May 2014 and analyzed for fluoride concentrations were overlaid on the final FCZ map. 340 Figure $3 \mathrm{~b}$ shows the superimposition of on-site fluoride sampling locations with the prepared 341 fluoride contamination zone map. Thereafter, an agreement between predicted FCZ (pixel with 342 FCZ values) and the measured fluoride concentration of respective locations have been checked 343 (Table 3). Overall, 52 wells out of 61 wells with fluoride concentrations are having an agreement 
344 concerning the respective fluoride contaminated zones. Therefore, it is prudent to conclude that

345 the map of FCZ zones predicts the occurrence of fluoride contamination with $85.24 \%$ accuracy.

\section{"Table 3 is about here"}

\section{$348 \quad 5.0$ Conclusions}

In the present work, a knowledge based MCDM based model coupled with the application of remote sensing and GIS techniques has been proven to be an efficient tool for mapping fluoride contamination zones (FCZ) using selected hydro-geo-meteorological parameters. The findings

352 were confirmed with a real fluoride concentration in wells obtained from 61 locations. The

353 validation of actual fluoride concentration with the proposed model exhibited an agreement of 354 around $85 \%$, signifying the accuracy of the final model output. The results of the study revealed 355 that $61.52 \%$ of the total area appeared as a safe zone, whereas $38.48 \%$ of the total area emerged 356 as unsafe zones i.e., areas with more than $1.5 \mathrm{mg} / \mathrm{L}$ fluoride concentration in groundwater.

357 The main advantage of the current study was the integration of a number of the hydro-geo358 meteorological thematic layers on a regional scale that can be successfully adapted to delineate 359 fluoride contaminated zones. In addition to this, the preciseness of model output to measure the 360 authenticity and reliability level can also be taken into consideration by cross checking the 361 generated output map with measured fluoride concentrations. Similarly, the major constraint of 362 this approach is the absence of comprehensive information on a regional scale, especially for 363 uneven distribution of reported fluoride point data and mineralogical composition of the rocks. In 364 spite of this limitation, such type of FCZ mapping has been attempted first time in the study area 365 in order to provide an insight into the potential fluoride contaminated zones. The FCZ map will 
366 be very much helpful for the researchers, planners, and administrators in assessing the severity of

367 contamination of fluoride concentration in groundwater. The FCZ map will also be helpful for

368 evaluating the regions of the study area in the need of drinking water free from fluoride

369 contamination. The unsafe zones can be identified for the construction of artificial recharge

370 structures for diluting the concentration of fluoride in groundwater along with other remedial

371 measures.

\section{Acknowledgements}

373 The authors express sincere thanks to the IIT (ISM), Dhanbad and CGWB management for the 374 facilities extended towards the publication of this paper. The ideology addressed in this paper, 375 solely belongs to the authors only and not necessarily of their organizations.

376

377

378

379

380

381

382 


\section{References}

Adimalla, N., Marsetty, S.K. and Xu, P., 2019. Assessing groundwater quality and health risks of fluoride pollution in the Shasler Vagu (SV) watershed of Nalgonda, India. Human and Ecological Risk Assessment: An International Journal, pp.1-20.

Adimalla, N. and Venkatayogi, S., 2017. Mechanism of fluoride enrichment in groundwater of hard rock aquifers in Medak, Telangana State, South India. Environmental Earth Sciences, $76(1)$, p.45.

Al-Abadi, A.M., Al-Shamma'a, A.M. and Aljabbari, M.H., 2017. A GIS-based DRASTIC model for assessing intrinsic groundwater vulnerability in northeastern Missan governorate, southern Iraq. Applied Water Science, 7(1), pp.89-101.

Al-Rawabdeh, A.M., Al-Ansari, N.A., Al-Taani, A.A., Al-Khateeb, F.L. and Knutsson, S., 2014. Modeling the risk of groundwater contamination using modified DRASTIC and GIS in Amman-Zerqa Basin, Jordan. Central European Journal of Engineering, 4(3), pp.264-280.

Ando, M., Tadano, M., Yamamoto, S., Tamura, K., Asanuma, S., Watanabe, T., Kondo, T., Sakurai, S., Ji, R., Liang, C. and Chen, X., 2001. Health effects of fluoride pollution caused by coal burning. Science of the total environment, 271(1-3), pp.107-116.

Arulbalaji, P., Padmalal, D. and Sreelash, K., 2019. GIS and AHP techniques based delineation of groundwater potential zones: a case study from southern Western Ghats, India. Scientific reports, $9(1)$, pp.1-17.

Bagyaraj, M., Ramkumar, T., Venkatramanan, S. and Gurugnanam, B., 2013. Application of remote sensing and GIS analysis for identifying groundwater potential zone in parts of Kodaikanal Taluk, South India. Frontiers of Earth Science, 7(1), pp.65-75.

CGWB (Central Ground Water Board), 2013. Ground Water Information Booklet, Jamui District, Bihar, India. p.4.

Dartan, G.U.L.E.R., Taspinar, F.A.T.I.H. and Toroz, I., 2017. Analysis of fluoride pollution from fertilizer industry and phosphogypsum piles in agricultural area. J. Ind. Pollut. Control, 33, pp.662-669.

Elewa, H.H. and Qaddah, A.A., 2011. Groundwater potentiality mapping in the Sinai Peninsula, Egypt, using remote sensing and GIS-watershed-based modeling. Hydrogeology Journal, 19(3), pp.613-628.

GSI (Geological Survey of India), 1987. A Geoscientific appraisal of Munger district, Bihar for rural development, Bulletin series B No. 49, GSI, Government of India. Plate V. 
Ghazavi, R. and Ebrahimi, Z., 2015. Assessing groundwater vulnerability to contamination in an arid environment using DRASTIC and GOD models. International journal of environmental science and technology, 12(9), pp.2909-2918.

Gonçalves, M.V.P., Santos, R.A., Coutinho, C.A.M. and Cruz, M.J.M., 2020. Fluoride Levels in the Groundwater and Prevalence of Dental Fluorosis in the Municipality of Santana, in Region Karstic of West Bahia, Brazil. In Groundwater Hydrology. Intech

Open.DOI: http://dx.doi.org/10.5772/ intechopen.85007.

Ibrahim-Bathis, K. and Ahmed, S.A., 2016. Geospatial technology for delineating groundwater potential zones in Doddahalla watershed of Chitradurga district, India. The Egyptian Journal of Remote Sensing and Space Science, 19(2), pp.223-234.

Kim, K. and Jeong, G.Y., 2005. Factors influencing natural occurrence of fluoride-rich groundwaters: a case study in the southeastern part of the Korean Peninsula. Chemosphere, 58(10), pp.1399-1408.

Kumar, S., Singh, R., Venkatesh, A.S., Udayabhanu, G. and Sahoo, P.R., 2019. Medical Geological assessment of fluoride contaminated groundwater in parts of Indo-Gangetic Alluvial plains. Scientific reports, 9(1), pp.1-16.

Kumar, S., Venkatesh, A.S., Singh, R., Udayabhanu, G. and Saha, D., 2018. Geochemical signatures and isotopic systematics constraining dynamics of fluoride contamination in groundwater across Jamui district, Indo-Gangetic alluvial plains, India. Chemosphere, 205, pp.493-505. https://doi.org/10.1016/j.chemosphere.2018.04.116.

Liu G, Ye Q, Chen W, Zhao Z, Li L and Lin P. 2015. Study of the relationship between the lifestyle of residents residing in fluorosis endemic areas and adult skeletal fluorosis. Environ. Toxicol. Pharmacol. 40 (1), 326-332.

Luo, W., Gao, X. and Zhang, X., 2018. Geochemical processes controlling the groundwater chemistry and fluoride contamination in the Yuncheng Basin, China-An area with complex hydrogeochemical conditions. PloS one, 13(7).

Machiwal, D., Jha, M.K. and Mal, B.C., 2011. Assessment of groundwater potential in a semiarid region of India using remote sensing, GIS and MCDM techniques. Water resources management, 25(5), pp.1359-1386.

Madhnure, P., Sirsikar, D.Y., Tiwari, A.N., Ranjan, B. and Malpe, D.B., 2007. Occurrence of fluoride in the groundwaters of Pandharkawada area, Yavatmal district, Maharashtra, India. Current Science, pp.675-679.

Mondal, N.C., Prasad, R.K., Saxena, V.K., Singh, Y. and Singh, V.S., 2009. Appraisal of highly fluoride zones in groundwater of Kurmapalli watershed, Nalgonda district, Andhra Pradesh (India). Environmental Earth Sciences, 59(1), pp.63-73. 
Pillai, K.S. and Stanley, V.A., 2002. Implications of fluoride--an endless uncertainty. Journal of Environmental Biology, 23(1), pp.81-87.

Preeja, K. R., Joseph, S., Thomas, J., and Vijith, H., 2011. Identification of groundwater potential zones of a tropical river basin (Kerala, India) using remote sensing and GIS techniques. Journal of the Indian Society of Remote Sensing, 39(1), pp.83-94.

Rahman, M.M., Bodrud-Doza, M., Siddiqua, M.T., Zahid, A. and Islam, A.R.M.T., 2020. Spatiotemporal distribution of fluoride in drinking water and associated probabilistic human health risk appraisal in the coastal region, Bangladesh. Science of The Total Environment, 724, p.138316.

Rao, N.S., 2009. Fluoride in groundwater, Varaha River Basin, Visakhapatnam District, Andhra Pradesh, India. Environmental Monitoring and Assessment, 152(1-4), p.47.

Rashid, M., Lone, M.A. and Ahmed, S., 2012. Integrating geospatial and ground geophysical information as guidelines for groundwater potential zones in hard rock terrains of south India. Environmental monitoring and assessment, 184(8), pp.4829-4839.

Saaty, T.L., 1980. The analytic hierarchy process: planning, priority setting, resource allocation (McGraw-Hill International Book Company).

Saaty, T.L., 2004. Fundamentals of the analytic network process-multiple networks with benefits, costs, opportunities and risks. Journal of systems science and systems engineering, 13(3), pp.348-379.

Sawangjang, B., Hashimoto, T., Wongrueng, A., Wattanachira, S. and Takizawa, S., 2019. Assessment of fluoride intake from groundwater and intake reduction from delivering bottled water in Chiang Mai Province, Thailand. Heliyon, 5(9), p. e 02391.

Senthilkumar, P., Nithya, J. and Babu, S.S., 2014. Assessment of groundwater vulnerability in Krishnagiri District, Tamil Nadu, India using DRASTIC approach. International Journal of Innovative Research in Science, Engineering and Technology, 3(3), p-253.

Shanker, R., Thussu, J.L. and Prasad, J.M., 1987. Geothermal studies at Tattapani hot spring area, Sarguja district, central India. Geothermics, 16(1), pp.61-76.

Singh, R., Syed, T.H., Kumar, S., Kumar, M. and Venkatesh, A.S., 2017b. Hydrogeochemical assessment of surface and groundwater resources of Korba coalfield, Central India: environmental implications. Arabian Journal of Geosciences, 10(14), p.318.

Singh, R., Venkatesh, A.S., Syed, T.H., Reddy, A.G.S., Kumar, M. and Kurakalva, R.M., 2017a. Assessment of potentially toxic trace elements contamination in groundwater resources of the coal mining area of the Korba Coalfield, Central India. Environmental Earth Sciences, 76(16), p.566. 
Singh, R., Venkatesh, A.S., Syed, T.H., Surinaidu, L., Pasupuleti, S., Rai, S.P. and Kumar, M., 2018. Stable isotope systematics and geochemical signatures constraining groundwater hydraulics in the mining environment of the Korba Coalfield, Central India. Environmental Earth Sciences, 77(15), p.548.

Singha, S.S., Pasupuleti, S., Singha, S., Singh, R. and Venkatesh, A.S., 2019a. Analytic network process based approach for delineation of groundwater potential zones in Korba district, Central India using remote sensing and GIS. Geocarto International, pp.1-23.

Singha, S., Pasupuleti, S., Durbha, K.S., Singha, S.S., Singh, R. and Venkatesh, A.S., 2019b. An analytical hierarchy process-based geospatial modeling for delineation of potential anthropogenic contamination zones of groundwater from Arang block of Raipur district, Chhattisgarh, Central India. Environmental Earth Sciences, 78(24), p.694.

Singha, S., Pasupuleti, S. and Villuri, V.G.K., 2017. An integrated approach for evaluation of groundwater quality in Korba district, Chhattisgarh using Geomatic techniques. Journal of Environmental Biology, 38(5), p.865.

Srivastava, S.K. and Ramanathan, A.L., 2018. Geochemical assessment of fluoride enrichment and nitrate contamination in groundwater in hard-rock aquifer by using graphical and statistical methods. Journal of Earth System Science, 127(7), p.104.

Su, H., Wang, J. and Liu, J., 2019. Geochemical factors controlling the occurrence of highfluoride groundwater in the western region of the Ordos basin, northwestern China. Environmental pollution, 252, pp.1154-1162.

Thapa, R., Gupta, S. and Kaur, H., 2017. Delineation of potential fluoride contamination zones in Birbhum, West Bengal, India, using remote sensing and GIS techniques. Arabian Journal of Geosciences, 10(23), p.527.

Thapa, R., Gupta, S., Guin, S. and Kaur, H., 2018. Sensitivity analysis and mapping the potential groundwater vulnerability zones in Birbhum district, India: A comparative approach between vulnerability models. Water Science, 32(1), pp.44-66.

Todd, K. D. and Mays. L.W., 2005. Groundwater Hydrology. Third ed. John Wiley and Sons, p.636.

Tossou, Y.Y.J., Orban, P., Gesels, J., Otten, J., Yessoufou, S., Boukari, M. and Brouyère, S., 2017. Hydrogeochemical mechanisms governing the mineralization and elevated fluoride $\$ \$$ left ( $\left\{\right.$ text $\left.\{\mathrm{F}\}^{\wedge}\{-\}\right\}$ \right) $\$$ contents in Precambrian crystalline aquifer groundwater in central Benin, Western Africa. Environmental Earth Sciences, 76(20), p.691.

Vithanage, M., Rajapaksha, A.U., Bootharaju, M.S. and Pradeep, T., 2014. Surface complexation of fluoride at the activated nano-gibbsite water interface. Colloids and Surfaces A: Physicochemical and Engineering Aspects, 462, pp.124-130. 
Wu, H., Chen, J. and Qian, H., 2016. A modified DRASTIC model for assessing contamination risk of groundwater in the northern suburb of Yinchuan, China. Environmental Earth Sciences, 75(6), p.483.

Xu, Y., Huang, H., Zeng, Q., Yu, C., Yao, M., Hong, F., Luo, P., Pan, X. and Zhang, A., 2017. The effect of elemental content on the risk of dental fluorosis and the exposure of the environment and population to fluoride produced by coal-burning. Environmental Toxicology and Pharmacology, 56, pp.329-339. 


\section{$591 \quad$ List of Tables}

592 Table 1: Details of the ten thematic layers along with their areal extents.

\begin{tabular}{|c|c|c|c|c|c|}
\hline Parameter & Subclass & Rating & $\begin{array}{c}\text { Normalized } \\
\text { weight }\end{array}$ & Area $\left(\mathrm{km}^{2}\right)$ & $\begin{array}{c}\text { Percentage } \\
\text { area }(\%)\end{array}$ \\
\hline Aquifer & $\begin{array}{c}\text { Alluvial } \\
\text { Biotite-muscovite-chloride schist } \\
\text { Granite gneiss } \\
\text { Quartizite, quartz schist and phyllite }\end{array}$ & $\begin{array}{c}4 \\
8 \\
10 \\
5\end{array}$ & 0.195 & $\begin{array}{l}113.67 \\
818.47 \\
505.75 \\
353.11\end{array}$ & $\begin{array}{c}6.35 \\
45.70 \\
28.24 \\
19.72\end{array}$ \\
\hline Geomorphology & $\begin{array}{c}\text { Alluvial plain } \\
\text { Denundational hill and Piedmont } \\
\text { Pediplain }\end{array}$ & $\begin{array}{l}4 \\
3 \\
9\end{array}$ & 0.096 & $\begin{array}{l}463.2 \\
729.7 \\
598.1\end{array}$ & $\begin{array}{l}25.86 \\
40.74 \\
33.39\end{array}$ \\
\hline Soil texture & $\begin{array}{l}\text { Coarse loamy soil } \\
\text { Fine loamy soil }\end{array}$ & $\begin{array}{l}9 \\
5\end{array}$ & 0.166 & $\begin{array}{l}457.60 \\
1333.40\end{array}$ & $\begin{array}{l}25.55 \\
74.45\end{array}$ \\
\hline Slope $(\%)$ & $\begin{array}{c}0-3 \% \\
3-6 \% \\
6-9 \% \\
9-12 \% \\
>12 \%\end{array}$ & $\begin{array}{l}9 \\
7 \\
5 \\
3 \\
1\end{array}$ & 0.021 & $\begin{array}{c}653.67 \\
625.73 \\
210.02 \\
64.59 \\
236.99\end{array}$ & $\begin{array}{c}36.50 \\
34.94 \\
11.73 \\
3.61 \\
13.23\end{array}$ \\
\hline Elevation & $\begin{array}{l}42-167 \\
167-292 \\
292-417 \\
417-542\end{array}$ & $\begin{array}{l}9 \\
6 \\
3 \\
1\end{array}$ & 0.021 & $\begin{array}{c}1414.77 \\
297.35 \\
69.71 \\
9.17\end{array}$ & $\begin{array}{c}78.99 \\
16.60 \\
3.89 \\
0.51\end{array}$ \\
\hline $\begin{array}{l}\text { Drainage density } \\
\left(\mathrm{km} / \mathrm{km}^{2}\right)\end{array}$ & $\begin{array}{c}0-3 \\
3 \text { to } 6 \\
6 \text { to } 9 \\
9 \text { to } 12 \\
>12\end{array}$ & $\begin{array}{l}9 \\
7 \\
5 \\
2 \\
1\end{array}$ & 0.100 & $\begin{array}{c}1264.49 \\
369.23 \\
103.7 \\
44.71 \\
8.87\end{array}$ & $\begin{array}{c}70.60 \\
20.62 \\
5.79 \\
2.50 \\
0.50\end{array}$ \\
\hline Rainfall (mm/year) & $\begin{array}{l}718-835 \\
835-952 \\
>952\end{array}$ & $\begin{array}{l}4 \\
6 \\
8\end{array}$ & 0.120 & $\begin{array}{c}116.85 \\
1224.71 \\
449.44\end{array}$ & $\begin{array}{c}6.52 \\
68.38 \\
25.09\end{array}$ \\
\hline Depth to water table (m) & $\begin{array}{c}0 \text { to } 3 \\
3 \text { to } 6 \\
6 \text { to } 9 \\
>9\end{array}$ & $\begin{array}{l}3 \\
5 \\
7 \\
9\end{array}$ & 0.170 & $\begin{array}{c}4.63 \\
1137.98 \\
633.77 \\
14.62\end{array}$ & $\begin{array}{c}0.26 \\
63.54 \\
35.39 \\
0.82\end{array}$ \\
\hline Land use land cover & $\begin{array}{c}\text { Barren rocky land with occasional scrub } \\
\text { Crop land } \\
\text { Fallow land } \\
\text { Forrest and plantation } \\
\text { Rural and urban settlement } \\
\text { Water body }\end{array}$ & $\begin{array}{l}9 \\
7 \\
3 \\
4 \\
1 \\
2\end{array}$ & 0.077 & $\begin{array}{l}287.39 \\
611.32 \\
358.83 \\
406.72 \\
65.82 \\
60.92\end{array}$ & $\begin{array}{c}16.05 \\
34.13 \\
20.04 \\
22.71 \\
3.68 \\
3.40\end{array}$ \\
\hline $\begin{array}{l}\text { Lineament density } \\
\left(\mathrm{km} / \mathrm{km}^{2}\right)\end{array}$ & $\begin{array}{c}0-0.5 \\
0.5-1.0 \\
1.0-1.5 \\
1.5-2.0\end{array}$ & $\begin{array}{l}2 \\
3 \\
4 \\
5\end{array}$ & 0.034 & $\begin{array}{c}1390.87 \\
156.77 \\
60.82 \\
50.81\end{array}$ & $\begin{array}{l}77.66 \\
8.75 \\
3.40 \\
2.84\end{array}$ \\
\hline
\end{tabular}


Table 2: Pair wise comparison matrix established amidst ten thematic layers.

\begin{tabular}{lllllllllll}
\hline Parameter & P1 & P2 & P3 & P4 & P5 & P6 & P7 & P8 & P9 & P10 \\
P1 & 1.00 & 2.00 & 1.00 & 3.00 & 3.00 & 2.00 & 2.00 & 4.00 & 6.00 & 6.00 \\
P2 & 0.50 & 1.00 & 1.00 & 3.00 & 3.00 & 2.00 & 3.00 & 3.00 & 5.00 & 5.00 \\
P3 & 1.00 & 1.00 & 1.00 & 2.00 & 2.00 & 2.00 & 3.00 & 4.00 & 6.00 & 6.00 \\
P4 & 0.33 & 0.33 & 0.50 & 1.00 & 2.00 & 2.00 & 3.00 & 4.00 & 5.00 & 5.00 \\
P5 & 0.33 & 0.33 & 0.50 & 0.50 & 1.00 & 1.00 & 3.00 & 4.00 & 6.00 & 6.00 \\
P6 & 0.50 & 0.50 & 0.50 & 0.50 & 1.00 & 1.00 & 2.00 & 3.00 & 6.00 & 6.00 \\
P7 & 0.50 & 0.33 & 0.33 & 0.33 & 0.33 & 0.50 & 1.00 & 5.00 & 6.00 & 6.00 \\
P8 & 0.25 & 0.33 & 0.25 & 0.25 & 0.25 & 0.33 & 0.20 & 1.00 & 2.00 & 2.00 \\
P9 & 0.17 & 0.20 & 0.17 & 0.20 & 0.17 & 0.17 & 0.17 & 0.50 & 1.00 & 1.00 \\
P10 & 0.17 & 0.20 & 0.17 & 0.20 & 0.17 & 0.17 & 0.17 & 0.50 & 1.00 & 1.00 \\
\hline
\end{tabular}

598 Table 3.Agreement details of measured fluoride concentration with fluoride contamination zones.

\begin{tabular}{|c|c|c|c|c|c|c|c|c|}
\hline $\mathrm{Sr}$ & Location & Longitude & Latitude & $\begin{array}{l}\text { Type of } \\
\text { Sample }\end{array}$ & $\begin{array}{c}\text { Catchment } \\
\text { Area } \\
\text { (Lithology) }\end{array}$ & $\begin{array}{c}\text { Fluoride } \\
\text { concentration } \\
(\mathrm{mg} / \mathrm{L})\end{array}$ & Zone & Agreement \\
\hline 1 & Bhimbandh & 86.3750 & 25.0620 & HP & & 0.01 & 6.09 & Agree \\
\hline 2 & Sikandara & 86.0500 & 24.9333 & HP & Alluviam & 0.08 & 6.71 & Disagree \\
\hline 3 & Maniadda & 86.2109 & 24.9580 & $\mathrm{HP}$ & Alluviam & 0.14 & 6.43 & Agree \\
\hline 4 & Nawadi & 86.0000 & 24.9020 & HP & Alluviam & 0.14 & 6.57 & Agree \\
\hline 5 & Corporation Bank & 86.1569 & 24.9267 & HP & Alluviam & 0.18 & 6.47 & Agree \\
\hline 6 & Kala & 86.4085 & 24.9654 & HP & Hard rock & 0.20 & 6.06 & Agree \\
\hline 7 & Manjhos & 86.1043 & 24.9600 & HP & Alluviam & 0.21 & 5.72 & Agree \\
\hline 8 & Bhemain & 86.2176 & 24.7882 & HP & Alluviam & 0.22 & 6.16 & Agree \\
\hline 9 & Domachak & 86.4108 & 24.9980 & $\mathrm{HP}$ & Hard rock & 0.23 & 6.70 & Disagree \\
\hline 10 & Amaratah & 86.1883 & 24.9536 & $\mathrm{HP}$ & Alluviam & 0.26 & 5.90 & Agree \\
\hline 11 & lakshmipur & 86.4031 & 25.0069 & HP & Hard rock & 0.26 & 6.30 & Agree \\
\hline 12 & Ratanpur & 86.2868 & 24.8992 & $\mathrm{HP}$ & Alluviam & 0.36 & 6.00 & Agree \\
\hline 13 & Jogia & 86.4032 & 25.0249 & $\mathrm{HP}$ & & 0.38 & 5.65 & Agree \\
\hline 14 & Fatehpur & 86.1879 & 24.8085 & $\mathrm{HP}$ & Hard rock & 0.44 & 6.35 & Agree \\
\hline 15 & Kamat & 86.2525 & 24.7503 & DW & Alluviam & 0.51 & 5.62 & Agree \\
\hline 16 & Dighi & 86.4309 & 24.9356 & $\mathrm{HP}$ & Alluviam & 0.52 & 6.03 & Agree \\
\hline 17 & jhajha & 86.3628 & 24.7890 & HP & Hard rock & 0.53 & 6.03 & Agree \\
\hline 18 & Purnakhaira & 86.1921 & 24.8768 & $\mathrm{HP}$ & Alluviam & 0.53 & 6.43 & Agree \\
\hline 19 & Gidhour & 86.3064 & 24.8564 & $\mathrm{HP}$ & Hard rock & 0.54 & 5.67 & Agree \\
\hline 20 & Sonai & 86.1900 & 24.9954 & HP & Alluviam & 0.55 & 6.46 & Agree \\
\hline 21 & Guguldih & 86.3181 & 24.9150 & $\mathrm{HP}$ & Alluviam & 0.61 & 6.22 & Agree \\
\hline 22 & Jhajah & 86.3640 & 24.7890 & DW & Hard rock & 0.66 & 6.03 & Agree \\
\hline 23 & Middle School, Barahat & 86.2939 & 25.0200 & $\mathrm{HP}$ & Hard rock & 0.67 & 5.78 & Agree \\
\hline 24 & Nawadi & 86.0000 & 24.9000 & DW & Alluviam & 0.68 & 6.39 & Agree \\
\hline 25 & Lakhuar & 86.0375 & 24.9611 & DTW & Alluviam & 0.70 & 5.88 & Agree \\
\hline 26 & Patneshwar Temple & 86.2407 & 24.9637 & HP & Hard rock & 0.78 & 6.14 & Agree \\
\hline 27 & Dighoi & 86.2139 & 24.9794 & $\mathrm{HP}$ & & 0.83 & 6.52 & Agree \\
\hline 28 & Dehuridih & 86.3000 & 24.7600 & $\mathrm{HP}$ & Alluviam & 0.88 & 4.98 & Agree \\
\hline
\end{tabular}




\begin{tabular}{|c|c|c|c|c|c|c|c|c|}
\hline 29 & JNV,Jamui & 86.2950 & 25.0024 & DTW & Hard rock & 0.88 & 6.88 & Disagree \\
\hline 30 & Barakhua,Barahat & 86.2804 & 24.9919 & HP & Hard rock & 0.91 & 6.50 & Agree \\
\hline 31 & Mahadeosimaria & 86.1341 & 24.9168 & DW & Alluviam & 1.03 & 6.71 & Disagree \\
\hline 32 & Mangobandar & 86.2656 & 24.8153 & HP & Hard rock & 1.06 & 6.06 & Agree \\
\hline 33 & Hardimoh & 86.2582 & 24.8464 & HP & Hard rock & 1.08 & 6.22 & Agree \\
\hline 34 & Cinbaria & 86.3410 & 24.9432 & HP & Alluviam & 1.17 & 6.27 & Agree \\
\hline 35 & Magahi & 86.3821 & 24.8845 & HP & Hard rock & 1.18 & 6.91 & Disagree \\
\hline 36 & Kenuhat & 86.3723 & 24.9908 & HP & Hard rock & 1.27 & 5.91 & Agree \\
\hline 37 & Sandipi & 86.4128 & 24.9354 & HP & Hard rock & 1.32 & 6.38 & Agree \\
\hline 38 & Dhamna & 86.3578 & 24.8521 & HP & Hard rock & 1.39 & 5.52 & Agree \\
\hline 39 & Gidheswar & 86.1799 & 24.8155 & DW & Hard rock & 1.40 & 6.62 & Agree \\
\hline 40 & ItaSagar & 86.0915 & 24.9108 & HP & Hard rock & 1.55 & 6.00 & Disagree \\
\hline 41 & Numer & 86.2967 & 24.9667 & HP & Hard rock & 1.56 & 6.81 & Agree \\
\hline 42 & Sindhu Mahodar & 86.4794 & 24.9071 & HP & & 1.57 & 7.13 & Agree \\
\hline 43 & Bhelbindo & 86.4458 & 24.8270 & HP & Hard rock & 1.63 & 7.41 & Agree \\
\hline 44 & Ragatraunia & 86.3705 & 24.7414 & $\mathrm{HP}$ & & 1.63 & 7.83 & Agree \\
\hline 45 & Darima & 86.1297 & 24.7954 & HP & & 1.70 & 6.75 & Agree \\
\hline 46 & New AbadiGanj & 86.3844 & 24.7865 & $\mathrm{HP}$ & Hard rock & 1.72 & 7.72 & Agree \\
\hline 47 & Sarebad & 86.2073 & 24.7671 & DW & Alluviam & 1.89 & 7.10 & Agree \\
\hline 48 & Harna & 86.4100 & 24.7593 & DW & Hard rock & 2.10 & 8.09 & Agree \\
\hline 49 & Bishanpur & 86.3160 & 24.9840 & TW & Hard rock & 2.21 & 7.20 & Agree \\
\hline 50 & Nargango & 86.3544 & 24.7454 & HP & & 2.40 & 7.68 & Agree \\
\hline 51 & Jokatia & 86.3544 & 24.7454 & HP & & 2.70 & 7.68 & Agree \\
\hline 52 & Lalmatia & 86.3000 & 24.9829 & HP & Hard rock & 2.90 & 7.66 & Agree \\
\hline 53 & Chandresekhar Nagar & 86.3553 & 24.8916 & HP & Hard rock & 3.00 & 7.24 & Agree \\
\hline \multirow[t]{2}{*}{54} & Primary $\mathrm{S}$ & & & HP & Hard rock & 3.08 & 7.37 & Agree \\
\hline & chooljeevanTola & 86.3800 & 24.8000 & & & & & \\
\hline 55 & Bhadwaria & 86.4624 & 24.7635 & HP & & 3.25 & 6.72 & Agree \\
\hline 56 & Majhwe & 86.1464 & 25.0360 & HP & Hard rock & 3.30 & 6.79 & Agree \\
\hline 57 & Prakash Nagar & 86.3880 & 24.8141 & HP & Hard rock & 3.34 & 6.51 & Disagree \\
\hline 58 & Panch Pahari & 86.3362 & 24.7469 & HP & & 3.50 & 7.63 & Agree \\
\hline 59 & Nabinagar & 86.1572 & 25.0292 & DTW & Hard rock & 5.30 & 6.78 & Agree \\
\hline 60 & Malaypur & 86.2625 & 24.9717 & DTW & Hard rock & 5.60 & 6.35 & Disagree \\
\hline 61 & Majhwe & 86.2625 & 24.9717 & DTW & Hard rock & 5.80 & 6.35 & Disagree \\
\hline
\end{tabular}

599

600

601

602

603

604

605

606

607

608

609 
$611 \quad$ List of Figures

612 Figure 1: Methodology adopted for portraying fluoride contamination zones (FCZ) in the 613 research area.

614 Figure 2: Spatial distribution of different thematic layers (a) Aquifer map (b) Geomorphological 615 pattern (c) Soil texture map (d) Slope map (e) Elevation map (f) Drainage density (g) Rainfall 616 distribution (h) Depth to water table (i) Land use land cover pattern (j) Lineament density map of 617 the study area.

618 Figure 3. (a) Fluoride contamination zone (FCZ) map of the study area. (b) Superimposition of 619 observation wells on the FCZ map.

620

621

622 


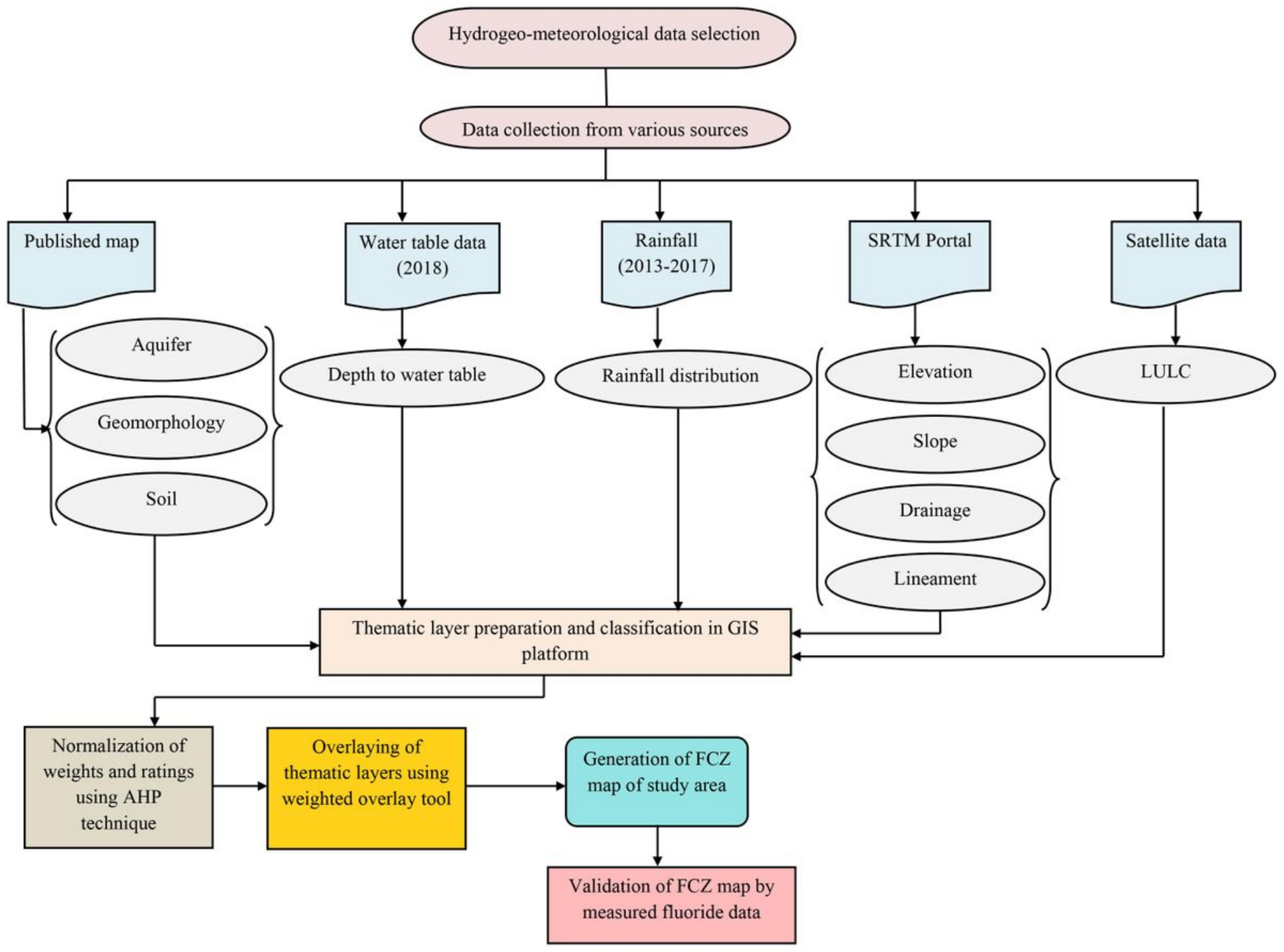

Figure 1

Methodology adopted for portraying fluoride contamination zones (FCZ) in the research area. 

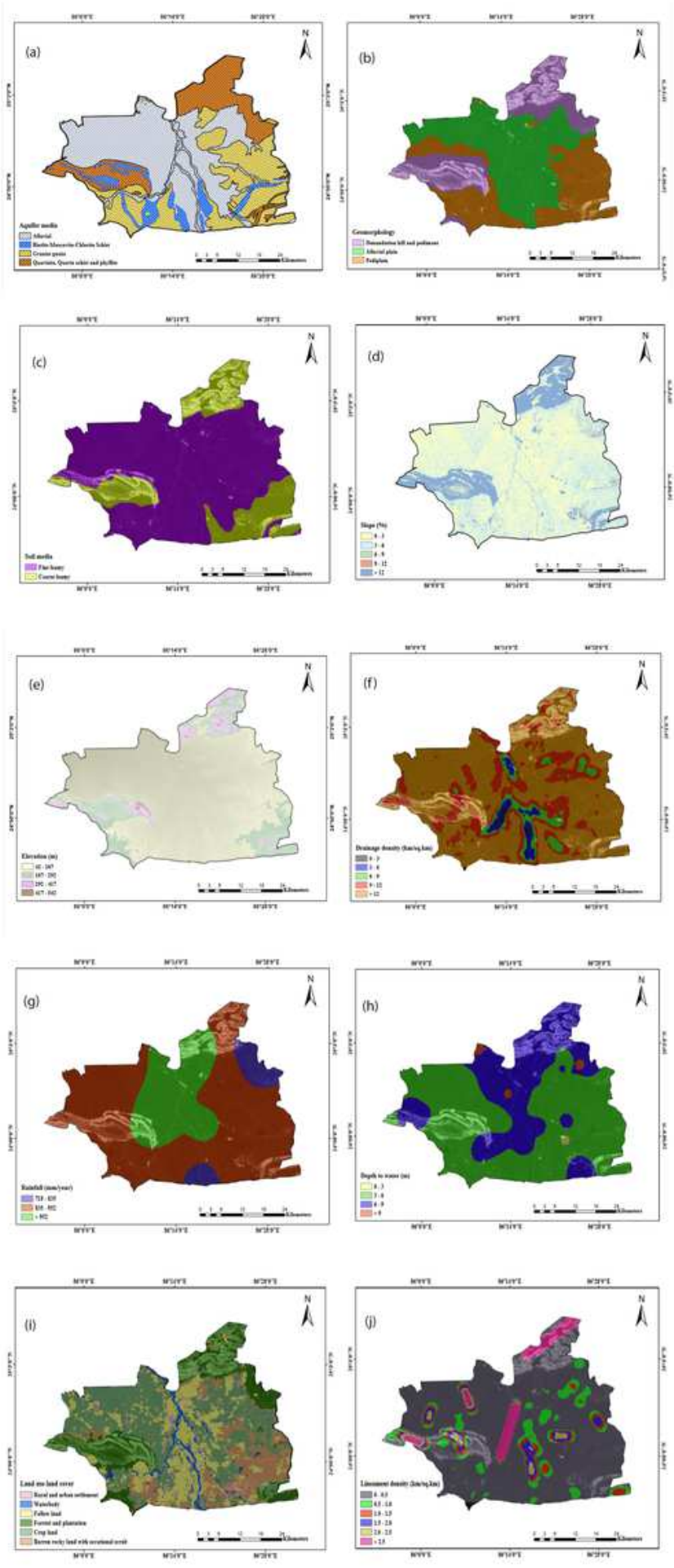

\section{Figure 2}

Spatial distribution of different thematic layers (a) Aquifer map (b) Geomorphological pattern (c) Soil texture map (d) Slope map (e) Elevation map (f) Drainage density (g) Rainfall distribution (h) Depth to water table (i) Land use land cover pattern (j) Lineament density map of the study area. Note: The designations employed and the presentation of the material on this map do not imply the expression of any opinion whatsoever on the part of Research Square concerning the legal status of any country, 
territory, city or area or of its authorities, or concerning the delimitation of its frontiers or boundaries. This map has been provided by the authors.
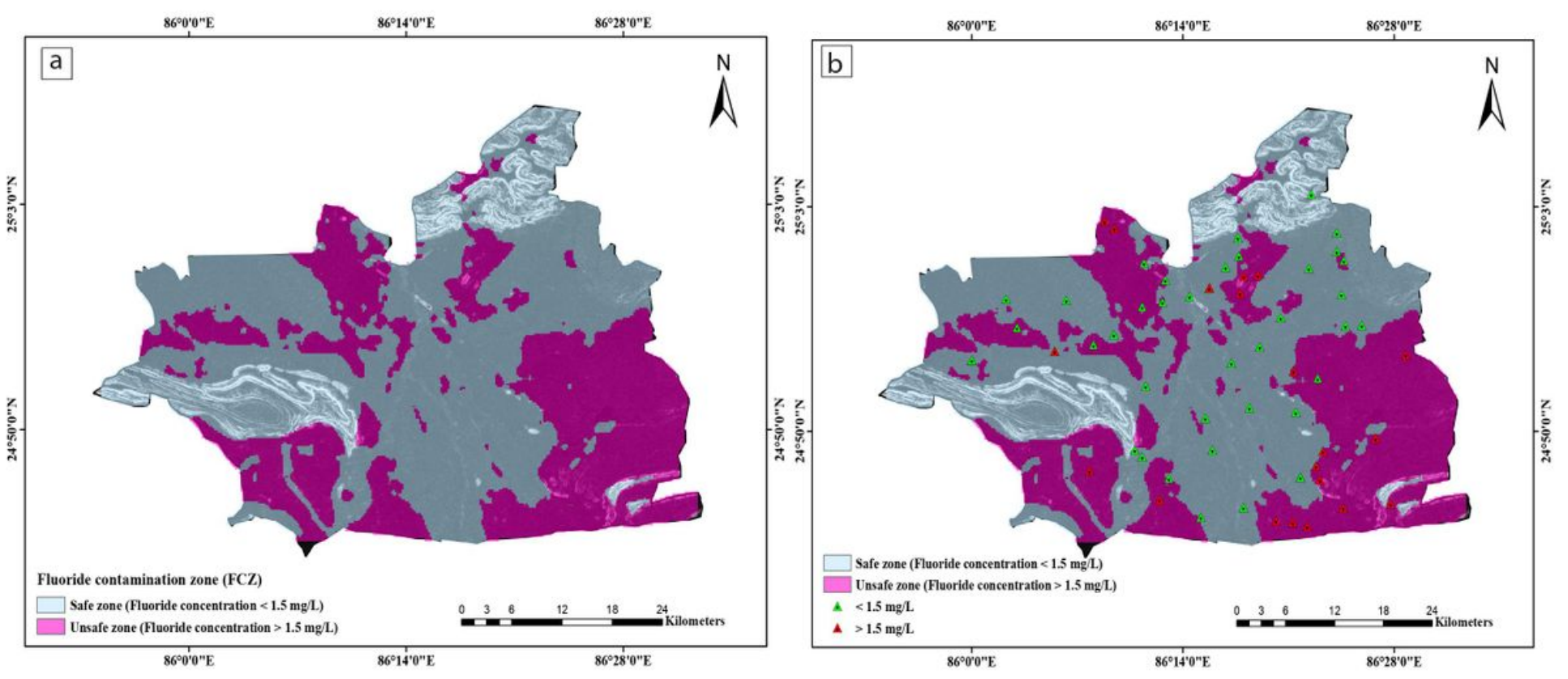

Figure 3

(a) Fluoride contamination zone (FCZ) map of the study area. (b) Superimposition of observation wells on the FCZ map. Note: The designations employed and the presentation of the material on this map do not imply the expression of any opinion whatsoever on the part of Research Square concerning the legal status of any country, territory, city or area or of its authorities, or concerning the delimitation of its frontiers or boundaries. This map has been provided by the authors. 